\title{
Development and state of the art of landscape science in Bulgaria
}

\section{Jordan Tzvetkov ${ }^{1,2, *}$}

\author{
${ }^{1}$ Space Research and Technology Institute, Bulgarian Academy of Sciences, Bulgaria \\ 2 St. Cyril and St. Methodius University of Veliko Tarnovo, Bulgaria \\ * Corresponding author: jordan.tzvetkov@gmail.com
}

\begin{abstract}
The establishment of International Association for Landscape Ecology (IALE), European Association for Landscape Ecology (IALE-Europe) and European Landscape Convention (2000) contribute and support the exchange of different concepts and methods in the field of landscape science, and also scientific cooperation between European countries. However, the specifics of landscape science in Bulgaria are little known outside the country. This article deals with the development and status of landscape science in Bulgaria. It describes its main stages in the historical development, its main characteristics and makes some general conclusions and critical notes about the future development of landscape science in Bulgaria.
\end{abstract}

\section{KEYWORDS}

Bulgaria; landscape science; landscape concepts; landscape methods

Received: 8 October 2020

Accepted: 23 July 2021

Published online: 6 September 2021

Tzvetkov, J. (2021): Development and state of the art of landscape science in Bulgaria. AUC Geographica 56(2), 195-204 https://doi.org/10.14712/23361980.2021.13

(C) 2021 The Author. This is an open-access article distributed under the terms of the Creative Commons Attribution License (http://creativecommons.org/licenses/by/4.0). 


\section{Introduction}

The landscape science in Bulgaria has long tradition but it is poorly known outside the country due to the fact that most of the publications are in Bulgarian language. So it is not surprise that although in Bulgaria exist two landscape classifications and maps on national level and many for the part of the country none of them is included in the systematic studies (Simensen et al. 2018). Several documents (European Landscape Convention from 2000) and scientific studies (Shaw and Oldfield 2007; Simensen et al. 2018) encourage international scientific exchange of different theoretical concepts and methodological approaches in the field of landscape science because of the very complicated nature of landscape, and multiple meanings of the landscape developed in different scientific, and cultural contexts (Antrop and Van Eetvelde 2017; Miklos et al. 2019). This results in the observations that only a significant variety of methods are possible to cover the many different aspects of landscape and the many different planning and management scopes. To support this scientific challenge several international cooperation activities exists. The most important of them are the International Association for Landscape Ecology (IALE), founded in 1982 in Piestany (Slovak Republic - former Czechoslovakia), and the European Association for Landscape Ecology (IALE-Europe), founded in 2009 in Salzburg (Austria).

The aims of this article are: 1) to trace the development of landscape science in Bulgaria, its roots and historical traditions; 2) to describe the main landscape directions and branches that are developed in Bulgaria; 3) to make some conclusions about the state of the art of landscape science in Bulgaria; 4) to point some of the main new challenges in the future development of landscape science in Bulgaria.

Here we will present an author's overview of the main landscape directions, its current state and general features, as well as some of the most notable and representative publications for each branch. More complete list of the landscape publications in Bulgaria is included in the monograph "Landscape Geography of Bulgaria" (Velchev et al. 2011), and also in the article of G. Zhelezov and S. Nedkov (2019). Briefly here we want not only to present some critical introduction in to the landscape science in Bulgaria for a broader audience, but also to stimulate a further discussion about its future development and scientific problems.

\section{Main periods in the development of landscape science in Bulgaria}

Following the periodization of A. Velchev et al. (2011) there are three main periods in the development of landscape science in Bulgaria: 1) Prior to World War II. 2) Between 1970s years and the end of 1980s years.
3) After the beginning of 1990s years. The last period we will divide in to two sub periods: 3a) Between 1990 s years and the beginning of the new millennium 2000. 3b) After the beginning of the 2000s.

During the first period to the landscapes in Bulgaria pay attention foreign scholars like T. Fisher, O. Maull and A. Burchard. First Bulgarian scholars who mention the term landscape in scientific works were Zheko Radev and Dimitar Yaranov. First publication dedicated to landscapes of Bulgaria was published by Ivan Batakliev with the title "Landscape division of Bulgaria" (Batakliev 1934) (Fig. 1). Later Ignat Penkov published the essay "Cultural landscape" (Penkov 1943). At that time the landscape publications in Bulgaria were influenced mostly by the German-speaking geographical science and the most notable scholars like S. Passage, A. Hettner, O. Maull, and H. Hassinger.

After the WWII the development of landscape science in Bulgaria was suspended. Professors D. Yaranov and I. Batakliev were released from Sofia University for political reasons. The other authors abandon the use of the term landscape and research on landscape topics.

The second period began in the early 1970s, when I. Ivanov, D. Dimitrov and P. Penchev published an article discussing the state of the art of physical geography in Bulgaria (Ivanov et al. 1970). In this publication they pay attention to the need to study natural complexes (systems): the landscapes. A little later was established the Department of Landscape Science at the Faculty of Geology and Geography of Sofia University, and the Section of Landscape Science at the Geographical Institute of the Bulgarian Academy of Sciences. A few years later, a number of authors began publishing researches on landscape topics. Among the first of them were P. Petrov, M. Georgiev, K. Mishev, and A. Velchev. Later, others were included, and the

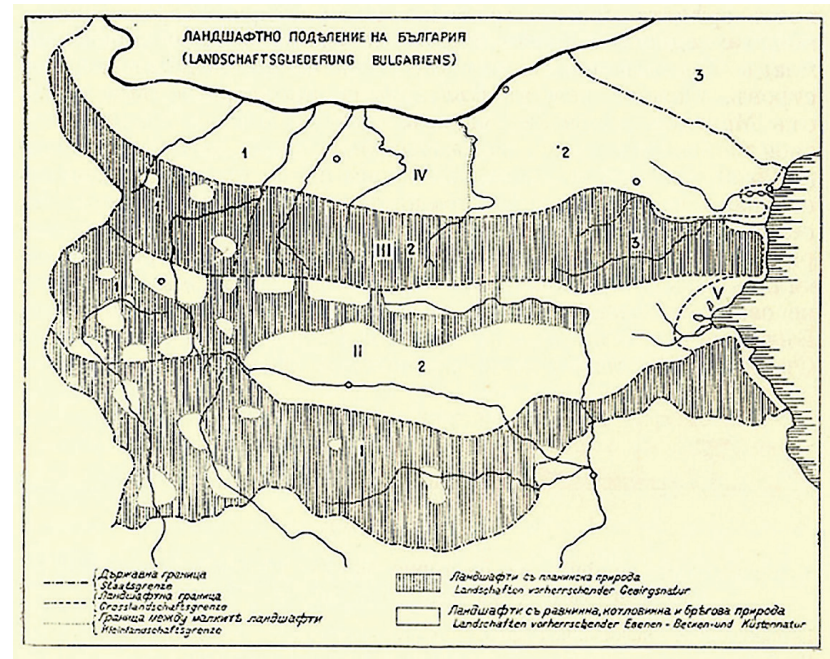

Fig. 1 Sketch map of landscape divisions of Bulgaria by Ivan Batakliev: area with hachures shows landscapes with mountain nature; area without hachures shows landscapes with plain, lowland and valley nature (Zhelezov 2020). 
number and thematic scope of publications increased significantly. At that time, Bulgarian landscape science was oriented and adopted the theoretical and methodological concepts of the landscape science developed in the former Soviet republics and especially in Russia. To a lesser extent was the influence of landscape concepts from other former socialist states such as the former East Germany, Poland and the former Czechoslovakia. This influence increased at the 1980 s, especially after the establishment of IALE in 1982 (in former Czechoslovakia).

The third period in the development of landscape science in Bulgaria started after 1990. During this period Bulgarian science opens to the theoretical and methodological concepts of landscape ecology developed in countries such as the former West Germany, USA, France and others. During the first sub period in the Bulgarian landscape science the theoretical concepts of landscape ecology began to spread and to be better known. During the second sub period (after the start of the European Landscape Convention in 2000 and its ratification by countries) not only theoretical but also methodological concepts from landscape ecology began to penetrate in the Bulgarian landscape studies. Also during this sub period the number of landscape publications published in international scientific journals by Bulgarian authors or with Bulgarian participation significantly increase.

\section{Basic theoretical concepts of landscape science in Bulgaria}

In the theoretical concepts of the Bulgarian landscape science the strongest is the imprint of the Russian landscape science (the Russian "landshaftovedenie"). It is based on the main contributions of Vasily Dokuchaev, who besides being known as the founder of modern soil science (Bockheim et al. 2005; Brevik and Hartemink 2010; Blinnikov 2011; Johnson and Schaetzl 2015; Rodrigo-Comino et al. 2017) has a contribution even to the environmental history of the steppes (Moon 2005). In the landscape science he is author of the essay "Toward the Study of the Zones of Nature" from 1899 in which he grounded the doctrine of the horizontal and altitudinal natural zones. Later in 1913, Lev Berg introduced the term landscape (from German "landschaft"), called Dokuchaev's natural zones landscape zones, and linked the science of landscape inseparably to the tradition of geography (Shaw and Oldfield 2007; Oldfield and Shaw 2016). In the essay "Toward the Study of the Zones of Nature", Dokuchaev wrote that in the past scholars studied "individual bodies - minerals, rocks, plants and animals - and phenomena, individual elements - fire (volcanism), water, earth, air, in which science has achieved amazing results, but not their relations, not this genetic, age-old and always regular connection that exists between forces, bodies and phenomena, between nonliving and living nature, between the plant, animal and mineral kingdoms on the one hand and man, with his way of life and even spiritual world - on the other" (Dokuchaev 1949). With this Dokuchaev continued those searches that Humboldt began (although Dokuchaev does not mention Humboldt explicitly) - the study of the relationship between living and nonliving nature (Wulf 2015; Antrop and Van Eetvelde 2017). Although Humboldt mention the landscape in his works primarily from a physiognomic and aesthetic point of view, he paves the way for future research into these complex relationships with the discovery of plant-climatic horizontal and altitudinal zonation (Humboldt and Bonpland 2009; Egerton 2009; Buttimer 2012; Debarbieux 2012; Arraes 2018). In German geography, the Humboldt's perspective was developed in the concept of landscape first by 0 . Schlüter and S. Passarge (Martin 2005).

In the conceptions of the landscape adopted by different authors, certain similarities and general positions can be established, as well as some differences, which we will try to summarize below. Among the characteristics of the landscape that are recognized by most authors we can outline the following: 1 ) the landscape is a complex system and like any system is made up of interacting and interdependent components; 2) the landscape has spatial integrity so it is a natural-territorial complex, limited in space and including all natural components of a given area ("spatial whole"); 3) the landscape does not have a specific biotic or abiotic center (unlike the ecosystem, which is biocentric) (Fig. 2); 4) the landscape is an open system that constantly interacts with the surrounding space - terrestrial and cosmic, as well as with society (human activity); 5) the landscape is a dynamic ("multidimensional") functional system, which is characterized by certain changes over time.

These characteristics constitute the basic theoretical core of the term landscape. At the same time, several directions are formed related to the differences in

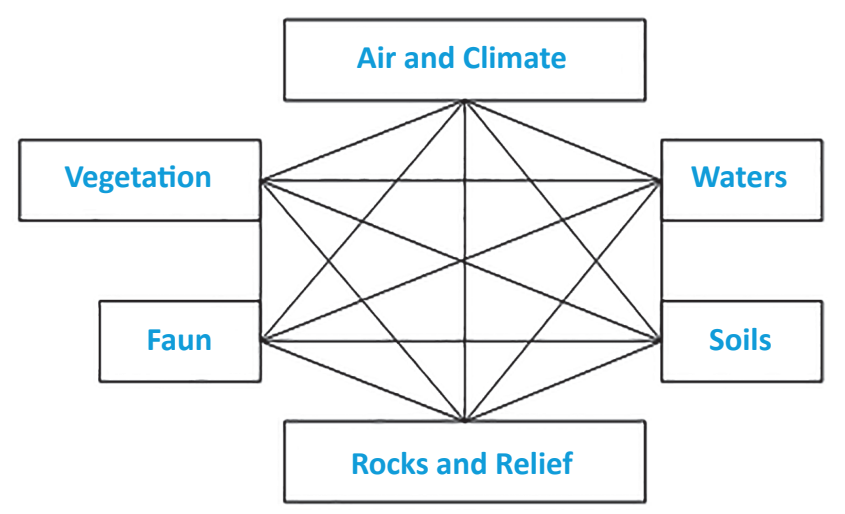

Fig. 2 Natural landscape as geosystem and "spatial whole" landscape components and their interconnections. 


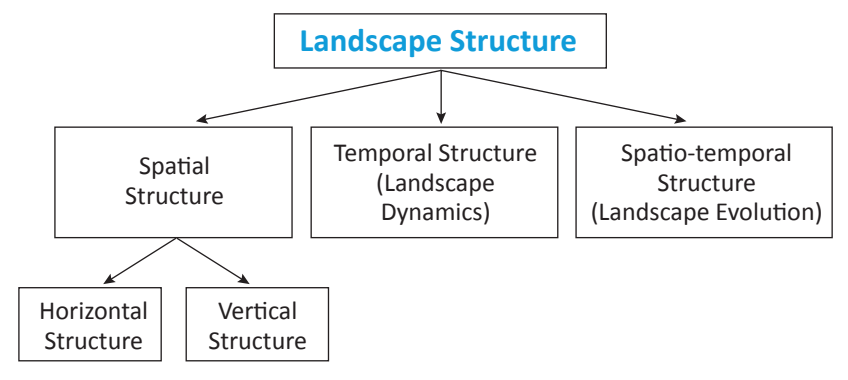

Fig. 3 Chart illustrating the different types of landscape structure.

the interpretation of the different groups of authors, in which the landscape can be understood differently: 1) as a geographical individual, a regional concept, which is one of the hierarchical levels in the physical-geographical differentiation; 2) as a typological concept of different rank, a result of a summary of certain characteristics of the territory, giving it relative homogeneity; 3) as a general concept, synonymous with a natural-territorial complex, both typological and regional.

In the Bulgarian landscape science the views about the landscape as a general concept or as a typological concept prevail (unlike in the Russia where the regional concept is the most widespread).

Apart from the term landscape, other concepts related to the subject of landscape research are also important to be described. One of them is the concept of the landscape structure (Fig. 3). In a narrower sense, the Latin term structure means a pattern, an arrangement of the parts that make up a particular object. In this narrow sense, it usually refers only to the spatial structure of landscapes, which in turn is horizontal and vertical.

In a broader sense, the general definition of structure is the spatio-temporal organization of the geosystems (Velchev et al. 2011). This, in turn, requires that not only the spatial but also the temporal aspect should be taken into account in the aspects of the structure. So some scholars distinguish also temporal structure and spatio-temporal structure both related with the landscape changes.

Many scholars accept the concept that landscape changes are divided into: evolution (or development) - qualitative, irreversible changes of the system; dynamics - mainly quantitative, conditionally reversible changes (for instance diurnal or seasonal changes) (Penin 2007).

\section{Main directions of landscape science in Bulgaria}

The landscape science in Bulgaria covers various directions and branches. Only the main of them will be described here. Some publications discuss theoretical questions and landscape concepts. A lot of them are concern with regional research and landscape mapping of specific parts of the country. Another main direction is landscape classification and also regionalization of the county based on landscape map. One direction witch is very extensive in its development is landscape geochemistry. Among with it a specific branch is landscape geophysics. We will discuss them in more detail below. Another very important branch in landscape researches is human impact on landscapes: landscape anthropogenisation (the study of different aspects of landscape transformation by human activity) and landscape deanthropogenisation (self-restoration of landscapes after reducing or terminating human activity). Several studies are concern with applied landscape science - landscape evaluation for specific purposes (agriculture, forestry, recreation etc.). Some new directions are landscape ecology and landscape planning, and also ecosystem services. Most of these directions are reflected in the university programs at master's levels (Penin and Konteva 2013).

Some of the most important publications in Bulgaria include: university textbooks (Petrov 1990; Penin 1997; Petrov 2011; Borisova 2013); monographs (Yakushko et al. 1983; Velchev and Petrov 1993; Velchev et al. 2011; Todorov and Velchev 2014; Cholakova 2018; Nam 2021); dictionaries (Penin 2007).

\section{Landscape classification and mapping - the study of the horizontal landscape \\ structure}

The landscape maps are common basis for characterisation of the horizontal landscape structure. The map's cartographic legend reflects the landscape classification. There are a wide variety of landscape classification schemes. At this stage, two classification systems have been developed and applied for

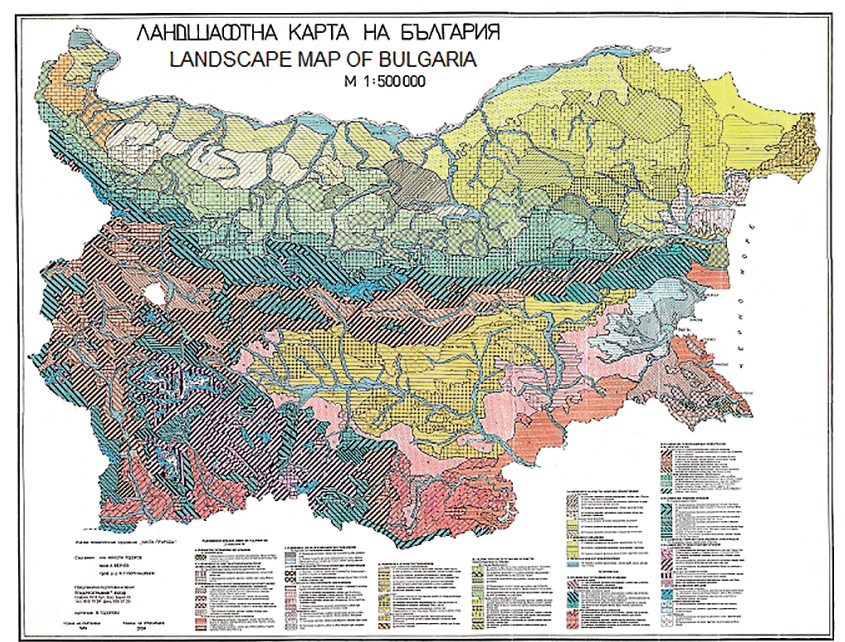

Fig. 4 The second landscape map of Bulgaria by A. Velchev et al., form 1992, at scale 1 : 500,000 (Prodanova and Petrova 2020). 


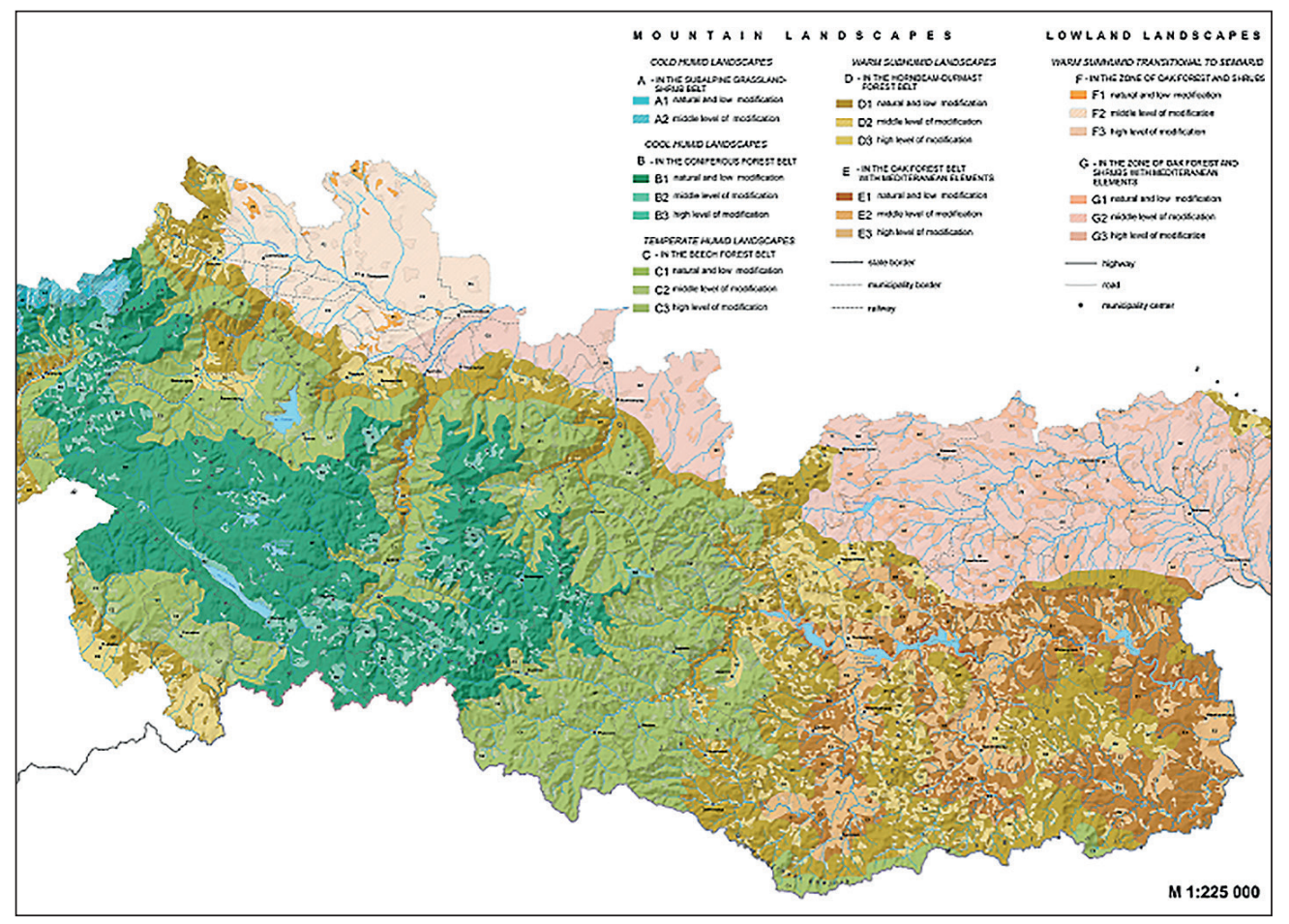

Fig. 5 Landscape map of Rhodopes at scale 1 : 225,000 (Gikov and Nedkov 2008).

the whole territory of Bulgaria. The first follows the classification scheme of N. Gvozdetsky and was used to compile a landscape map of Bulgaria at a scale of 1 : 400,000 (Petrov 1979). The second follows the classification scheme of N. Beruchashvili and was used to compile a landscape map of Bulgaria at a scale of $1: 500,000$ (Velchev et al. 1992) (Fig. 4). Along with them, a number of variants and modifications of the above two classifications and even completely new classifications have been proposed, which have been applied only to certain parts of the country (Velchev et al. 2011; Petrov 2011).

The two landscape maps of Bulgaria represent only the natural (potential) landscapes not taking in to account the landscape anthropogenic modifications. There is currently no landscape map at national level representing cultural landscapes or so called contemporary landscapes. Such maps exist only for the parts of the country. A good example for modern landscape mapping of contemporary landscapes with implementation of GIS is the "Atlas of Contemporary Landscapes of Rhodopes" (Gikov and Nedkov 2008) (Fig. 5).

The first landscape web-map was compiled for Vitosha Mountain (Tzvetkov 2017; see internet sources) and it includes two maps: of potential landscapes (Fig. 6) and of landscape anthropogenic modifications (Fig. 7).

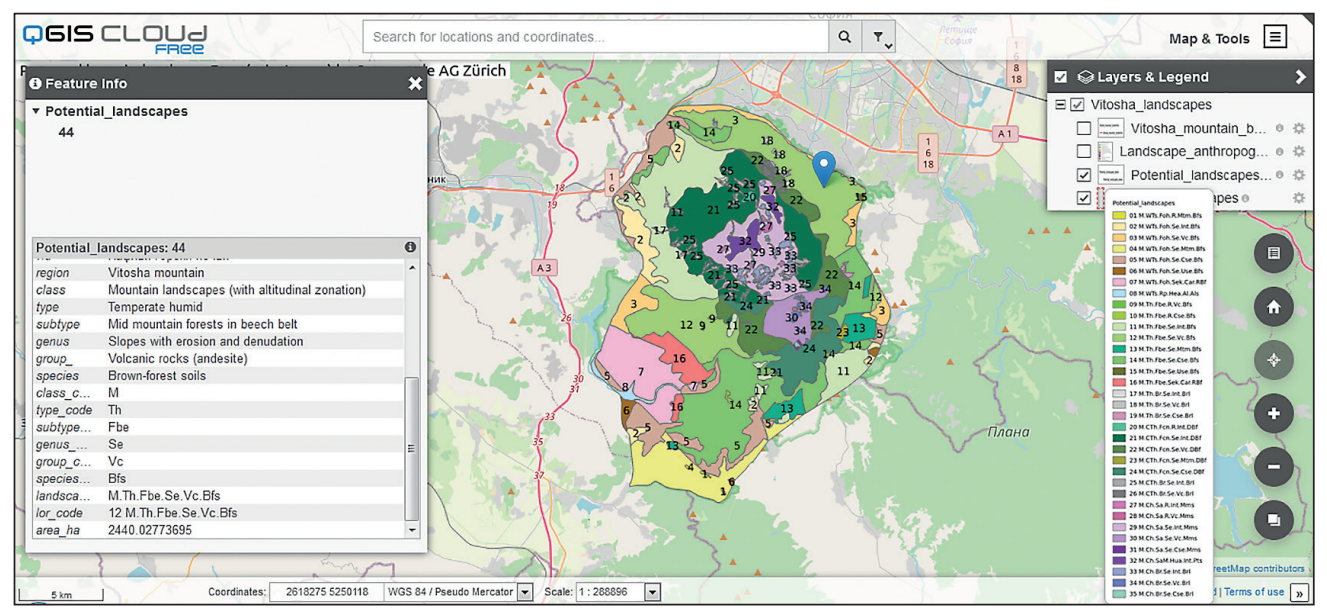

Fig. 6 Web-map of potential landscapes of Vitosha Mountain with feature info window. 


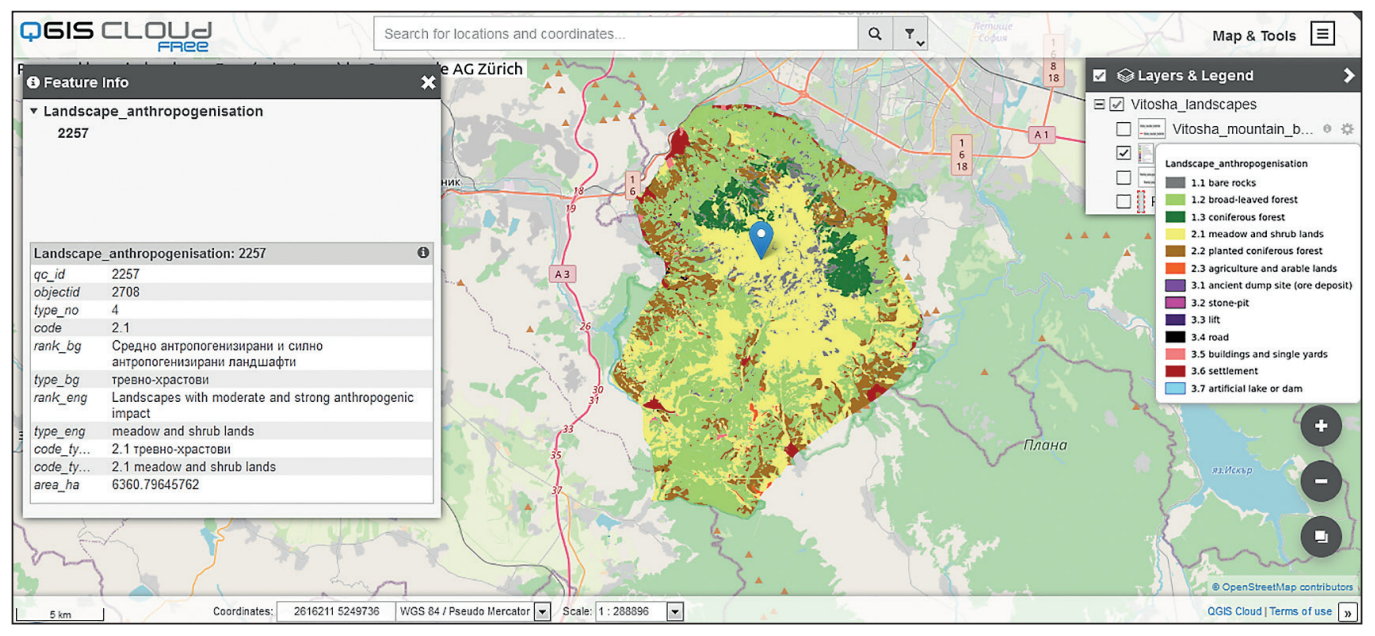

Fig. 7 Web-map of landscape anthropogenisation of Vitosha Mountain with feature info window showing the attributes of the selected feature.

\section{Landscape geophysics - the study of the vertical landscape structure and landscape dynamics}

The landscape geophysics is related to the study of the physical properties of geosystems - the processes of exchange of matter, energy and information, both within the geosystems themselves and between geosystems. In Bulgaria landscape geophysics follows a specific school developed by the Georgian geographer N. Beruchashvili (Gachechiladze et al. 2017). He developed his own theoretical concepts and methodological approaches to study the vertical landscape structure and landscape dynamics (Beruchashvili 1986, 1990). These methods can be applied on field, semi-stationary and stationary researches. Generally in this approach he distinguishes so called geomasses - elementary structural and functional parts of the landscape. They are qualitatively heterogeneous bodies characterized by a certain mass, specific functional purpose, rate of change in time and speed of movement in space. He defines the following seven classes of geomasses: aeromasses, phytomasses, zoomasses, mortmasses (mass of dead organic matter), lithomasses, pedomasses and hydromasses. Each class is subdivided in to diffident types and subtypes and all of them have short indexes (abbreviations). Geomasses differs from landscape components (see Fig. 2) with greater material homogeneity. The component is practically a complex formation and different geomasses are present in it, but one of them

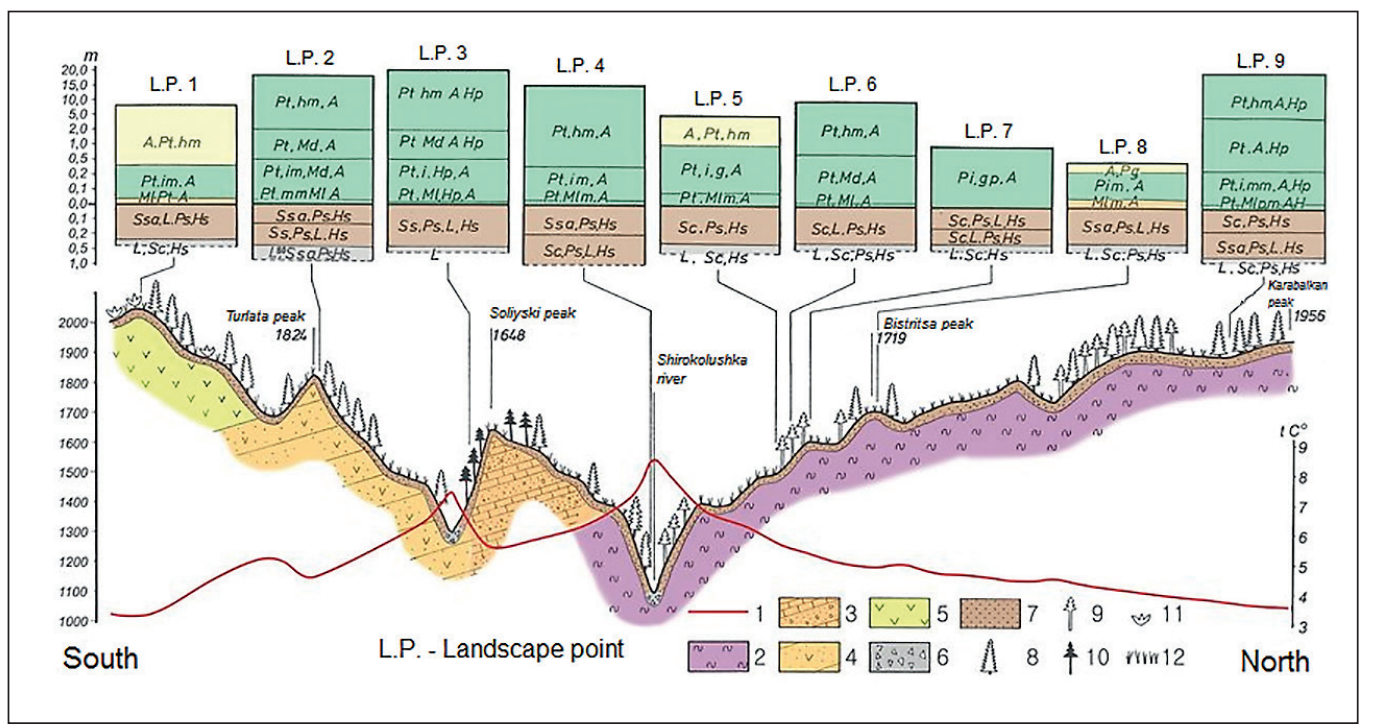

Fig. 8 Landscape profile in Rhodopes with nine landscape points and their landscape geophysical characteristic showing vertical structure described as geohorizons. Legend: 1) Mean annual temperature; 2) Metamorphic rocks; 3) Paleogene sedimentary rocks; 4) Paleogene sedimentary and volcanic rocks; 5) Paleogene volcanic rocks; 6) Alluvial deposit; 7) Brown forest soils; 8) Picea abies; 9) Pinus sylvestris; 10) Pinus nigra; 11) Juniperus sp.; 12) Herbaceous vegetation (Nikolova et al. 1997). 
always prevails and is the basis for its substrate. Also he proposes that the vertical structure of the elementary landscapes may be presented as different geohorizons, which are homogeneous combinations (layers) of a certain set of geomasses, characterized by a series of specific landscape-geophysical features. The main characteristics of geohorizons are: thickness; complexity (number of geohorizons); intensity (number of geohorizons per $1 \mathrm{~m}$ of the vertical profile) and composition (the set of specific geohorizons for a given landscape). For instance a part of this research approach and its visualization is shown on Fig. 8.

These methods for field and stationary researches are applied mostly in Southwestern Bulgaria (Todorov, Velchev 2014). Here is situated also the only one landscape stationary in Bulgaria (scientific base of Sofia University "St. K. Ohridski") near the city of Zemen, Pernik district (Velchev and Petrov 1993).

\section{Landscape geochemistry - the study of the chemical elements in landscapes}

The behavior of atoms in natural processes is a research subject of many sciences, which leads to the emergence of a number of interdisciplinary scientific fields. At the boundary between geography and chemistry is the landscape geochemistry, studying the history and behavior of atoms in landscapes. Among its important goals are to reveal the patterns in the migration, concentration and differentiation of chemical elements and compounds in the landscapes (Perel'man and Kasimov 1999). The founders of this branch are B. Polinov, M. Glazovskaya, A. Perel'man and also V. Vernadsky, and A. Fersman. They developed the theoretical and methodological basis of the landscape geochemistry both for scientific and for practical proposes. The former include many different tasks from discovering of ore deposits to environmental pollution assessment (Perelman and Kasimov 1999; Kasimov 2013).

The concepts of landscape geochemistry are known in different countries from Poland (Ostaszewska 2010) to Canada (Fortescue 1992) and China (Yu et al. 2019). Several scholars have pointed out that landscape geochemistry has more in common with the better known to the international scientific community environmental geochemistry (Fortescue 1992; Yu et al. 2019).

In Bulgaria it is widely used for environmental assessment of some trace elements (e.g. $\mathrm{Cu}, \mathrm{Zn}, \mathrm{Pb}$, $\mathrm{Cd}, \mathrm{As}, \mathrm{Co}, \mathrm{Cr}, \mathrm{Ni}, \mathrm{Mn}$ etc.) and its pollution. For several decades of researches all over the country the data accumulation allows estimating the geogenic (for background regions) and technogenic (for polluted regions) concentrations of some trace elements in soils and bottom sediments of the country (Penin 2003) as it is shown on Fig. 9 and Fig. 10.

\section{Ecosystem services - the evaluation and mapping of landscape and ecosystem services}

The study of ecosystem services is a brand new direction in landscape ecology. It spread fast thought the scientific community and penetrates in Bulgaria where several scholars were involved in to it (Zhelezov and Nedkov 2019). This lead to a new international scientific collaborations and a series of publications, most notable of which are connected with regional studies and ecosystem valuation (Nedkov 2011; Nedkov and Burkhard 2012) as well as novel methods for mapping ecosystem services (Burkhard et al. 2012). The research and assessment of the ecosystem services are mainly concerned in the mountain areas of the country, although several researches are accomplished in municipalities with more diverse landscapes (Nedkov et al. 2018a), in urban landscapes (Nedkov et al. 2018b), and for natural heritage on national level (Ihtimanski et al. 2020). Some of these studies are included in comparative analysis of case studies in EU and allow involving Bulgaria in intensive international exchange of theory, methods and policy in the field of ecosystem services (Geneletti et al. 2020).

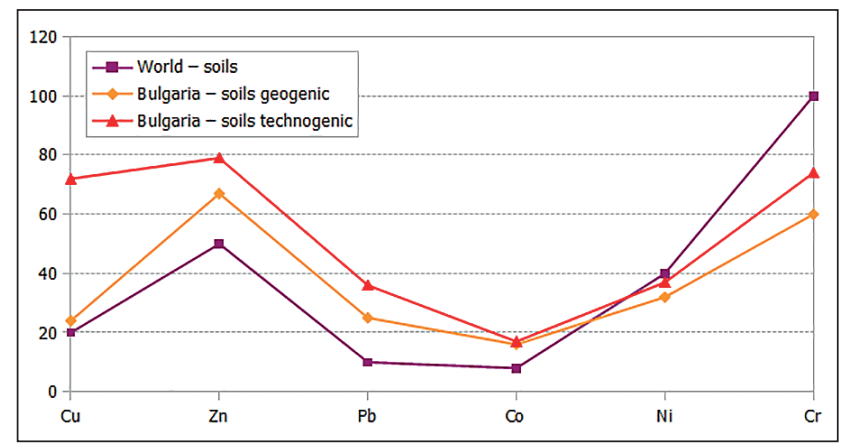

Fig. 9 Diagram shows some trace element concentrations (in ppm) in world soils (Kirkham 2008), Bulgaria - soils geogenic regions (Penin 2003), Bulgaria - soils technogenic regions (Penin 2003).

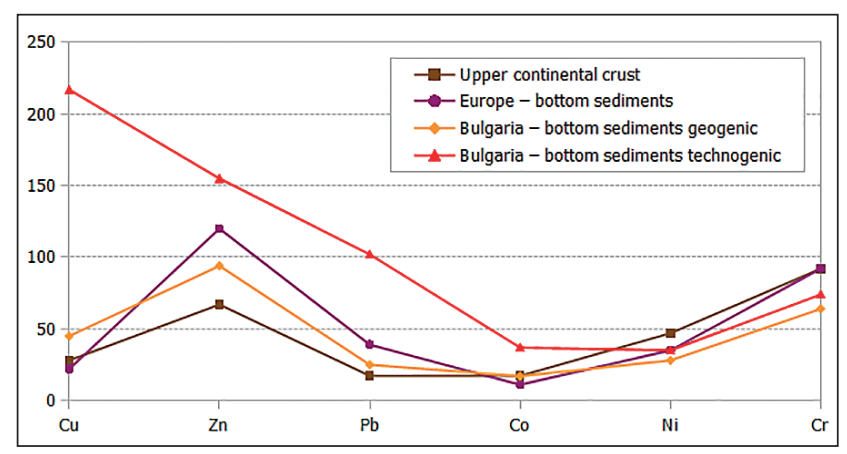

Fig. 10 Diagram shows some trace element concentrations (in ppm) in upper continental crust (Rudnick and Gao 2014), Europe - bottom sediments (Salminen 2005), Bulgaria - bottom sediments geogenic regions (Penin 2003), Bulgaria - bottom sediments technogenic regions (Penin 2003). 


\section{Conclusions}

Several important conclusions are possible to express about the development and state of the art of landscape science in Bulgaria. Here we will try to outline the pros and cons as well as not only past and current features but also the future trends.

The development of landscape science in Bulgaria has long traditions but its development was not continuous through the years. From 1945 to 1970 there is a hiatus in this development due to the political reasons. Also during some periods (e.g. between 1945 and 1990) its development was strongly dependent by the political development of the country and this political context has its imprint to the whole scientific development. This is common for every former socialist's country but even in this every country has its own specifics and among with the political context also cultural and personal factors shape the development of landscape science in Bulgaria.

The landscape science in Bulgaria store some theoretical and methodological concepts influenced by Russian landscape science which imprint a specific scientific content. This content differ form some widely (if not globally) adopted concepts of the landscape ecology. This in turn is an obstacle for international collaborations. In an attempt to overcome this it is crucial to reevaluate these concepts and to preserve best of these traditions keeping some of the most valuable concepts. (The hastily tendency to abandon most if not all of them may lead to the paradox that in time they will have to be rediscovered.) But that is not enough. These concepts should be developing further and at least but not last they should be spread to the international scientific exchange. Here we propose that the concept of landscape as geosystem, spatial integrity of landscape, the "multidimensional" view of landscape (the concepts of landscape structure), and the landscape typology are core scientific approaches.

During the last decades in Bulgarian landscape science penetrate some theoretical and methodological concepts form the landscape ecology. However these concepts are still relatively little known and even less applied in specific studies in Bulgaria. This is valid especially for statistical landscape analysis methods.

One significant disadvantage of the current state of the landscape science is that Bulgaria still don't has a digital landscape map which presents the contemporary landscapes ("cultural landscapes") and its anthropogenic modifications created by the modern GIS. This is a key factor for slowing the development of landscape science in Bulgaria and also for impedes the application of landscape theory in practice and in landscape planning.

One specific advantage is the strong developing of the landscape geochemistry but is should be more linked to the practice of governmental institutions in environmental protection and public health management. During the last years there is a trend to abandon the landscape geophysics. Some scholars shift their scientific interests to new branches like remote sensing and ecosystem services. This trend is a result of the implementation of new methods and the tendency to expansion of the remote sensing and GIS and reduction of the "old fashion" field methods.

Here we argue and call that the further development of landscape science in Bulgaria should preserve the main branches described above, and continue to enrich with new ones. This enrichment should be done in more intensive participation of Bulgarian scientist in to international activities connected with the International Association for Landscape Ecology (IALE), European Association for Landscape Ecology (IALE-Europe), and also other international scientific and research networks (like Landscape Europe, Landscape Tomorrow, UNISCAPE, CIVILSCAPE etc.).

\section{Acknowledgments}

I would like to express by gratitude to Galin Petrov and two anonymous reviewers for his critical notes and proposals which improve the manuscript.

\section{References}

Antrop, M., Van Eetvelde, V. (2017): Landscape Perspectives: The Holistic Nature of Landscape. Dordrecht, Springer, https://doi.org/10.1007/978-94-024-1183-6.

Arraes, E.A. (2018): A apreensão sensível da natureza em Goethe e Humboldt. Paisagem E Ambiente 42, 11-22, https://doi.org/10.11606/issn.2359-5361.v0i42p11-22.

Batakliev, I. (1934): Landscape divisions of Bulgaria. Annual of Sofia Univ., Faculty of History and Philology 30(13), 3-43 (in Bulgarian).

Blinnikov, M. (2011): A Geography of Russia and Its Neighbors. New York, The Guilford Press.

Bockheim, J., Gennadiyev, A., Hammer, R., Tandarich, J. (2005): Historical development of key concepts in pedology. Geoderma 124(1-2), 23-36, https://doi .org/10.1016/j.geoderma.2004.03.004.

Beruchashvili, N. (1986): Four Dimensions of Landscape. Moscow, Misl (in Russian).

Beruchashvili, N. (1990): Landscape Geophysics. Moscow, Viyshaya shkola (in Russian).

Borisova, B. (2013): Landscape Ecology and Landscape Planning. Sofia, Acad. Press. "Prof. M. Drinov" (in Bulgarian).

Brevik, E., Hartemink, A. (2010): Early soil knowledge and the birth and development of soil science. Catena 83(1), 23-33, https://doi.org/10.1016/j.catena.2010.06.011.

Burkhard, B., Kroll, F., Nedkov, S., Müller, F. (2012): Mapping ecosystem service supply, demand and budgets. Ecological Indicators 21, 17-29, https://doi.org/10.1016 /j.ecolind.2011.06.019.

Buttimer, A. (2012): Alexander von Humboldt and planet earth's green mantle. Cybergeo: European Journal of Geography [Online], Epistemology, History, Teaching, doc. 616, online 03 August 2012, http://journals .openedition.org/cybergeo/25478. 
Cholakova, Z. (2018): Karst and Karst Natural Systems. Sofia, Neofeedback (in Bulgarian).

Debarbieux, B. (2012): The various figures of mountains in Humboldt's science and rhetoric. Cybergeo: European Journal of Geography [Online], Epistemology, History, Teaching, doc. 618, online 21 August 2012, http:// journals.openedition.org/cybergeo/25488.

Dokuchaev, V. V. (1949): Collected Works. Moscow, AN SSSR (in Russian).

Egerton, F. (2009): A history of the ecological sciences, part 32: Humboldt, nature's geographer. The Bulletin of the Ecological Society of America 90(3), 253-282, https:// doi.org/10.1890/0012-9623-90.3.253.

Fortescue, J. (1992): Landscape geochemistry: retrospect and prospect - 1990. Applied Geochemistry 7(1), 1-53, https://doi.org/10.1016/0883-2927(92)90012-R.

Gachechiladze, R., Nikolaishvili, D., Bolashvili, N., Jamaspashvili, N. (2017): Scientific heritage of Professor Nikoloz Beruchashvili (1947-2006). Earth Sciences 6(5-1), 111-122, https://doi.org/10.11648/j.earth .s.2017060501.25.

Geneletti, D., Adem Esmail, B., Cortinovis, C., Arany, I., Balzan, M., van Beukering, P., Bicking, S., Borges, P., Borisova, B., Broekx, S., Burkhard, B., Gil, A., Inghe, O., Kopperoinen, L., Kruse, M., Liekens, I., Lowicki, D., Mizgajski, A., Mulder, S., Nedkov, S., Ostergard, H., Picanço, A., Ruskule, A., Santos-Martín, F., Sieber, I., Svensson, J., Vačkářů, D., Veidemane, K. (2020): Ecosystem services mapping and assessment for policy- and decision-making: Lessons learned from a comparative analysis of European case studies. One Ecosystem 5: e53111, https://doi.org/10.3897 /oneeco.5.e53111.

Gikov, A., Nedkov, S. (2008): Atlas of Contemporary Landscapes of Rhodopes. Project Rhodopes. Project Rhodopes - UN Development Program.

Humboldt, A., Bonpland, E. (2009): Essay on the Geography of Plants. Edited by S. Jackson. Translated by S. Romanowski. (First edition Paris, 1805). Chicago, Univ. of Chicago Press.

Ihtimanski, I., Nedkov, S., Semerdzhieva, L. (2020): Mapping the natural heritage as a source of recreation services at national scale in Bulgaria. One Ecosystem 5: e54621, https://doi.org/10.3897/oneeco.5.e54621.

Ivanov, I., Penchev, P., Dimitrov, D. (1970): State of the art, tasks and perspectives of physical geography in Bulgaria. Journal of the Bulgarian Geographical Society 10, 3-13 (in Bulgarian).

Johnson, D., Schaetzl, R. (2015): Differing views of soil and pedogenesis by two masters: Darwin and Dokuchaev. Catena 237-238, 176-189, https://doi.org/10.1016 /j.geoderma.2014.08.020.

Kasimov, N. (2013): Landscape Ecogeochemistry. Moscow, IP Filimonov (in Russian).

Kirkham, B. (2008): Trace elements. In: Chesworth W. (ed.). Encyclopedia of Soil Science. Dordrecht, Springer, 786-790.

Martin, G. (2005): All Possible Worlds: A History of Geographical Ideas (4th edn). N. Y., Oxford, Oxford Univ. Press.

Miklos, L., Kočicka, E., Izakovičova, Z., Kočicky, D., Špinerova, A., Diviakova, A., Miklosova, V. (2019): Landscape as Geosystem. Cham, Springer, https://doi .org/10.1007/978-3-319-94024-3.
Moon, D. (2005): The environmental history of the Russian steppes: Vasilii Dokuchaev and the harvest failure of 1891. Transactions of the Royal Historical Society 15, 149-174, https://doi.org/10.1017 /S0080440105000320.

Nam, K. (2021): Anthropogenic landscapes. Sofia, Univ. Press "St. K. Ohridski" (in Bulgarian).

Nikolova, N., Gikov, A., Kotsev, T., Zhelezov, G. (1997): Landscapes investigations in the crests Chernatitsa and Mursalitsa of the Milddle Rhodopes. In: Spiridonov H. (ed.). Geography Today. Sofia, Filvest, 95-109 (in Bulgarian).

Nedkov, S. (2011): Landscape structure and ecosystem services of Etropole municipally. In: Zhelezov G. (ed.). Sustainable Development in Mountain Regions: Southeastern Europe. Dordrecht, Springer, 85-94, https://doi.org/10.1007/978-94-007-0131-1_8.

Nedkov, S., Burkhard, B. (2012): Flood regulating ecosystem services - Mapping supply and demand, in the Etropole municipality, Bulgaria. Ecological Indicators 21, 67-79, https://doi.org/10.1016/j.ecolind.2011.06.022.

Nedkov, S., Borisova, B., Koulov, B., Zhiyanski, M., Bratanova-Doncheva, S., Nikolova, M., Kroumova, J. (2018a): Towards integrated mapping and assessment of ecosystems and their services in Bulgaria: The Central Balkan case study. One Ecosystem 3: e25428, https:// doi.org/10.3897/oneeco.3.e25428.

Nedkov, S., Zhiyanski, M., Borisova, B., Nikolova, M., Bratanova-Doncheva, S., Semerdzieva, L., Ihtimanski, I., Nikolov, P., Aidarova, Z. (2018b): A geospatial approach to mapping and assessment of urban ecosystem services in Bulgaria. European Journal of Geography 9 (4), 34-50.

Ostaszewska, K. (2010): The geochemical landscape concept and its usefulness in geography. Miscellanea Geographica 14, 5-12, https://doi.org/10.2478/mgrsd -2010-0001.

Oldfield, J., Shaw, D. (2016): The Development of Russian Environmental Thought: Scientific and Geographical Perspectives of the Natural Environment. New York, Routledge, https://doi.org/10.4324/9781315670171.

Penin, R. (1997): Practical Handbook of Landscape Geochemistry. Sofia, Univ. Press "St. K. Ohridski" (in Bulgarian).

Penin, R. (2003): Landscape geochemistry: A priority scientific branch in detection and solving environmental problems. In: Konteva M., Penin R. (eds). Thirty Years Department of Landscape Science and Environmental Protection. Sofia, Maleo-63-Varna, 89-94 (in Bulgarian).

Penin, R. (2007): Physical Geography and Landscape Ecology: A Dictionary of Terms. Sofia, Bulvest 2000 (in Bulgarian).

Penin, R., Konteva, M. (eds). (2013): Forty Years Department of "Landscape Science and Environmental Protection". Sofia, Bulvest 2000 (in Bulgarian).

Penkov, I. (1943): Cultural landscape. Journal of the Bulgarian Geographical Society, 10, 63-126 (in Bulgarian).

Perelman, A., Kasimov, N. (1999): Landscape Geochemistry. Moscow, Astreya-2000 (in Russian).

Petrov, P. (1979): A classification system of the landscapes in Bulgaria. Annual of Sofia Univ., Faculty of Geology and Geography 70(2), 159-181 (in Bulgarian).

Petrov, P. (1990): Landscape Science. Sofia, Sofia Univ. Press (in Bulgarian). 
Petrov, G. (2011): Practical Handbook of Landscape Science. Veliko Tarnovo, Univ. Press "St. Kiril and Metodii" (in Bulgarian).

Prodanova, H., Petrova, M. (2020): Assoc. Prof. PhD Nikola Todorov (1955-2018) - A life dedicated to geography. Journal of the Bulgarian Geographical Society 42, 115-131 (in Bulgarian).

Rodrigo-Comino, J., Senciales, J., Cerda, A., Brevik, E. (2017): The multidisciplinary origin of soil geography: A review. Earth-Science Reviews 117, 114-123, https://doi.org /10.1016/j.earscirev.2017.11.008.

Rudnick, R., Gao, S. (2014): Composition of the continental crust. In: Holland, H., Turekian, K. (eds). Treatise on Geochemistry (2nd edn) 4, 1-51, https://doi.org/10 .1016/B978-0-08-095975-7.00301-6.

Salminen, R. (ed.). (2005): Geochemical Atlas of Europe. Part 1: Background Information, Methodology and Maps. Espoo, Geological Survey of Finland, http://weppi.gtk.fi /publ/foregsatlas/index.php.

Shaw, D., Oldfield, J. (2007): Landscape science: A Russian geographical tradition. Annals of the Association of American Geographers 97(1), 111-126, https://doi.org /10.1111/j.1467-8306.2007.00526.x.

Simensen, T., Halvorsen, R., Erikstad, L. (2018): Methods for landscape characterisation and mapping: A systematic review. Land Use Policy 75, 557-569, https://doi.org/10 $.1016 / j . l a n d u s e p o l .2018 .04 .022$.

Todorov, N., Velchev, A. (2014): Landscapes of Bulgaria: Spatial Structure. Veliko Tarnovo, Ivis (in Bulgarian).

Tzvetkov, J. (2017): A web-map of the landscapes of Vitosha Mountain and the development of landscape science in Bulgaria. Forum geographic 16(2), 126-131, https:// doi.org/10.5775/fg.2017.023.d.

Velchev, A., Todorov, N., Assenov, A., Beruchashvili, N. (1992): A landscape map of Bulgaria at scale 1:500 000. Annual of Sofia Univ., Faculty of Geology and Geography 84(2), 85-107 (in Bulgarian).
Velchev, A., Petrov, P. (eds). (1993): Physical Geography and Landscape Researches in the Vicinity of Zemen Stationary. Sofia, Univ. Press "St. K. Ohridski” (in Bulgarian).

Velchev, A., Penin, R., Todorov, N., Konteva, M. (2011): Landscape Geography of Bulgaria. Sofia, Bulvest 2000 (in Bulgarian).

Wulf, A. (2015): The Invention of Nature: Alexander von Humboldt's New World. N. Y., Vintage Books.

Yakushko, P., Martsinkevich, G., Petrov, P., Velchev, A. (1983): Landscape Anthropogenisation in Belarus and Bulgaria. Sofia, Sofia Univ. Press (in Russian).

Yu, H., Li, R., Wang, G., Wang, Q. (2019): Current development of landscape geochemistry with support of geospatial technologies: A review. Critical Reviews in Environmental Science and Technology 49(9), 745-790, https://doi.org/10.1080/10643389.2018.1558890.

Zhelezov, G. (2020): Prof. Ivan Batakliev - Builder of the geographical sciences in Bulgaria. Journal of the Bulgarian Geographical Society 42, 18-23 (in Bulgarian).

Zhelezov, G., Nedkov, S. (2019): Development of the landscape researches in Bulgaria. - Problems of Geography 2, 71-85 (in Bulgarian).

\section{Internet sources}

Web-map of landscapes in Vitosha Mountain URL's: Webmap: http://qgiscloud.com/jdgis/Vitosha_landscapes WMS: http://wms.qgiscloud.com/jdgis/Vitosha_ landscapes

The classifications of the potential landscapes and landscape anthropogenisation impact in Vitosha, presented like full attributive tables of the GIS layers can be found on the following URL: https://goo.gl/EKHWxH 